4 27

\title{
Lability of copper bound to humic acid
}

Affiliation address: Division of Agricultural and Environmental Sciences, School of

6 Biosciences, University of Nottingham, Sutton Bonington Campus, Loughborough,

7 Leicestershire LE12 5RD, United Kingdom

8

*Corresponding Author

Scott Young: scott.young@ nottingham.ac.uk; Tel. +44(0)1159516256

1 Postal Address: Gateway Building, Sutton Bonington Campus, Loughborough, Leicestershire,

2 LE12 5RD, United Kingdom

3 Lingchen Mao: lingchen_mao@163.com

4 Liz Bailey: liz.bailey@ nottingham.ac.uk

Mao, L., Young, S.D. and Bailey, E.H. 2015. Lability of copper bound to humic acid.

Chemosphere, 131, 201 - 208.

doi:10.1016/j.chemosphere.2015.03.035

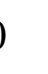

\section{HIGHLIGHTS:}

3 - Isotopic dilution was used to assess the lability of $\mathrm{Cu}$ bound to humic acids

4 - Time-dependent $\mathrm{Cu}$ fixation by humic acid was observed over 160 days

5 - Around $40 \%$ of $\mathrm{Cu}$ bound to HA may be non-labile.

26 - Non-labile $\mathrm{Cu}$ in humic acids may affect predicted speciation by geochemical models 
Geochemical speciation models generally include the assumption that all metal bound to humic acid and fulvic acid (HA, FA) is labile. However, in the current study, we determined the presence of a soluble 'non-labile' $\mathrm{Cu}$ fraction bound to HA extracted from grassland and peat soils. This was quantified by determining isotopically-exchangeable $\mathrm{Cu}$ (E-value) and EDTA-extraction of HA-bound $\mathrm{Cu}$, separated by size-exclusion chromatography (SEC) and assayed by coupled ICP-MS. Evidence of time-dependent $\mathrm{Cu}$ fixation by $\mathrm{HA}$ was found during the course of an incubation study (160 days); up to 50\% of dissolved HA-bound $\mathrm{Cu}$ was not isotopically exchangeable. This result was supported by extraction with EDTA where approximately $40 \%$ of $\mathrm{Cu}$ remained bound to $\mathrm{HA}$ despite dissolution in $0.05 \mathrm{M} \mathrm{Na}_{2}$-EDTA. The presence of a substantial non-labile metal fraction held by HA challenges the assumption of wholly reversible equilibrium which is central to current geochemical models of metal binding to humic substances.

\section{Keywords}

43 Humic acid, Non-labile metal, WHAM model, Isotopic dilution, EDTA extraction, SEC-ICPMS

\section{Introduction}

Geochemical models, such as WHAM-VII (Lofts and Tipping, 2011; Tipping, 1998) and the NICA-Donnan Model (Kinniburgh et al., 1999), include the assumption that trace metals sorbed on humic substances are entirely labile - i.e. they participate in a reversible dynamic equilibrium with free metal ions. However, there is increasing evidence that a non-labile fraction may exist in sub-micron sized colloidal phases and bound to dissolved species. For example, in a study of 18 soils, Ma et al. (2006) found non-isotopically exchangeable $\mathrm{Cu}$ in the solution phase filtered through $0.2 \mu \mathrm{m}$ cellulose acetate filters; they suggested the $\mathrm{Cu}$ was likely to be associated with dissolved organic matter. Similar suggestions have been made by the same research group (Lombi et al., 2003; Nolan et al., 2009) for Ni, Cu and Zn. Jackson et al. (2005) in a study of dissolved organic matter (DOM) in river water, measured Ni and U distribution in a colloidal phase separated by size exclusion chromatography (SEC) or flow field-flow fractionation (FIFFF) and concluded that Ni was 'more labile' than U because $\mathrm{Ni}^{2+}$ appeared to interact with the SEC column gel phase and the FIFFF membrane to a greater 
degree. By contrast Laborda et al. (2011), used asymmetrical flow field flow fractionation (AsFIFFF) to separate dispersed colloidal phases of isotopically spiked compost material and, from measurements of the isotopic ratio within different size fractions including the free inorganic phase, they concluded that all $\mathrm{Cu}$ and $\mathrm{Pb}$ present was isotopically exchangeable .

It is accepted that metals can be held by very strong binding sites on humic substances through the formation of 'multidentate' complexes with carboxylic and phenolic groups or by specific binding with $\mathrm{N}$ and $\mathrm{S}$ groups which are known to preferentially bind metals such as $\mathrm{Cr}^{\mathrm{III}}, \mathrm{Fe}^{\mathrm{III}}, \mathrm{Cu}$ and $\mathrm{Hg}$ (Tipping, 2002). However, strong chemical bond formation does not necessarily result in non-labile complex formation and there have been very few studies that have attempted to determine the presence of such a metal fraction on dissolved humic substances. It is well established that isotopic dilution (ID) approaches and some chemical extractants (eg $0.05 \mathrm{M}$ EDTA) can be used to estimate the labile fraction of trace metals in soils (Degryse et al., 2009; Gabler et al., 2007). However, to measure metal lability on a dissolved system containing a range of metal complex species requires a fractionation technique to separate high MW DOM-bound metal from low MW organic and inorganic complexes. This approach then also allows fractionation of spike isotopes introduced to follow the kinetics of metal assimilation throughout the various species and quantification of the isotopically exchangeable forms present. Size exclusion chromatography (SEC) coupled with inductively coupled plasma mass spectrometry (ICP-MS) has been applied to the study of trace element distributions within humic acids (Jackson et al., 2005; Kozai et al., 2013; Liu and Cai, 2010; Liu et al., 2011; Schmitt et al., 2001).

The aim of this investigation was to determine the lability of $\mathrm{Cu}$ bound to dissolved humic acid (HA) to test the hypothesis that $\mathrm{Cu}$ bound to dissolved HA is labile. To achieve this, two popular techniques for measuring labile metals in soils were modified and applied to two types of HAs fractionated using SEC-ICP-MS: extraction with EDTA and determination of isotopic exchangeability. Dissolved HA was incubated with an enriched stable $\mathrm{Cu}$ isotope and its subsequent extractability with EDTA determined from differences in isotopic abundance between forms bound to HAs and to low MW complexes with EDTA. Humic acid solutions were incubated with $\mathrm{Cu}$ (normal isotopic mix) for a period of time before they were spiked with an enriched stable $\mathrm{Cu}$ isotope. The proportion of dissolved HA-bound metal that was isotopically exchangeable (\% E-values; Smolders et al., 1999; Young et al., 2000) was then determined from changes in isotope distribution between $\mathrm{Cu}$ complexes with HAs 


\section{Materials and Methods}

\subsection{Humic acid preparation and characterisation}

Two humic acids were previously extracted and purified by Marshall et al. (1995) from a permanent grassland soil (G-HA; Nottinghamshire, UK) and Sphagnum moss peat (P-HA; North Yorkshire, UK). The ash content was measured by dry combustion at $500^{\circ} \mathrm{C}$ for 8 hours as $23.5 \mathrm{~g} \mathrm{~kg}^{-1}$ and $3.9 \mathrm{~g} \mathrm{~kg}^{-1}$ for G-HA and P-HA respectively. Total acid group concentrations determined by Marshall et al. (1995) were $5.50 \mathrm{~mol}_{\mathrm{c}} \mathrm{kg}^{-1}$ for G-HA and 6.94 $\mathrm{mol}_{\mathrm{c}} \mathrm{kg}^{-1}$ for P-HA using a modified $\mathrm{Ba}(\mathrm{OH})_{2}$ method (Schnitzer and Khan, 1972) including a pre-dissolution step in $0.1 \mathrm{M} \mathrm{NaOH}$ to ensure complete hydration of the HA. In this study, the freeze dried HAs were dissolved in $0.5 \mathrm{M} \mathrm{NaOH}$ and $\mathrm{pH}$ adjusted to 7.0 with dilute nitric acid to provide working HA stock solutions of $16.0 \mathrm{~g} \mathrm{~L}^{-1}$.

\subsection{Size-exclusion chromatography (SEC-ICP-MS)}

Fractionation of HA based on molecular size was undertaken using size-exclusion chromatography (SEC) with an ICS-3000 chromatography system (Thermo-Fisher Scientific) and a Superose 12 10/300 GL column (GE Healthcare) with a separation range from 1000 to 300,000 Da. A guard column (Hamilton, Peek PRP-X100) was installed prior to the SEC column. Humic acid samples of $100 \mu \mathrm{L}$ were injected into an eluent comprising 0.1 M Tris buffer at $\mathrm{pH} 8.2$ adjusted with nitric acid at a flow rate of $1 \mathrm{ml} \mathrm{min}^{-1}$. The $\mathrm{pH}$ of the eluent was chosen to coincide broadly with the maximum buffer power of the Tris $(\mathrm{pKa}=8.1)$ and the equivalence-point of carboxyl groups on the HA. The column outflow was connected directly to the nebuliser of an ICP-MS (XSeries ${ }^{\mathrm{II}}$; Thermo-Fisher Scientific) operating in 'collision cell with kinetic energy discrimination' mode (7\% hydrogen in helium) to reduce polyatomic interferences (e.g. ${ }^{35} \mathrm{Cl}^{-35} \mathrm{Cl}$ interference with ${ }^{70} \mathrm{Zn}$ ). The minimum and maximum quadrupole settle times were adjusted to $1000 \mu \mathrm{s}$, to minimize the effects of plasma flicker, and $\mathrm{Cu}$ isotopes $\left({ }^{63} \mathrm{Cu} \&{ }^{65} \mathrm{Cu}\right)$ were measured with a quadrupole dwell time of $40 \mathrm{~ms}$. The instrument 'dead time correction factor' was set to $37.2 \mathrm{~ns}$ after establishing the value which gave a zero slope in a plot of isotope ratio against concentration of $\mathrm{Pb}$ in solutions of the $\mathrm{Pb}$ isotope standard NIST-981. The ICP-MS was directly calibrated with both $\mathrm{Cu}$ isotopes, precluding the need for internal or external mass discrimination. For pragmatic reasons (nebuliser capacity) we did not include an internal standard line downstream of the SEC 
124 column. For discrete sample analysis which may vary in matrix composition this is vital but considering (i) the use of standard additions for calibration (Section 2.5), (ii) prior knowledge of the total $\mathrm{Cu}$ concentration in each sample and (iii) the constancy of the eluent matrix, we did not consider that addition of an internal standard would improve reliability of data. In practice, we found very high reproducibility of chromatograms without an internal standard. A sample loop flushing step between each sample was standard on the SEC chromatography program to avoid carryover and cross-contamination. Chromatographic data were collected for 34 min but typically the data of interest were integrated between 5 and $25 \mathrm{~min}$.

\subsection{Determination of Cu extractable by EDTA from humic acid}

133 A stable isotope of $\mathrm{Cu}$ with enriched isotopic abundance (IA) was purchased from ISOFLEX 134 USA as a metal foil and dissolved in concentrated $\mathrm{HNO}_{3}$. Dissolved humic acid, at concentrations of $4.0 \mathrm{~g} \mathrm{~L}^{-1}$ (G-HA) or $4.4 \mathrm{~g} \mathrm{~L}^{-1}$ (P-HA), were incubated with the diluted stable isotope solution: $168 \mu \mathrm{g} \mathrm{L}^{-165} \mathrm{Cu}$ (IA $\geq 99.0 \%$ ). The $\mathrm{Cu}$ concentration was chosen to be high enough to give a measurable ICP-MS signal after complex-formation. The concentration of functional groups (total acidity) in the dissolved HA solutions $\left(\mathrm{mol}_{\mathrm{c}} \mathrm{L}^{-1}\right)$ was calculated from the values provided by Marshall et al. (1995), as $0.022 \mathrm{~mol}_{\mathrm{c}} \mathrm{L}^{-1}$ for G-HA and $0.031 \mathrm{~mol}_{\mathrm{c}} \mathrm{L}^{-1}$ for P-HA, while the spiked isotope solution contained $2.6 \times 10^{-6} \mathrm{~mol}_{\mathrm{c}} \mathrm{L}^{-1}$ of $\mathrm{Cu}$. After equilibration for 40 or 160 days at $18^{\circ} \mathrm{C}$ the spiked solutions were diluted with $0.1 \mathrm{M}$ Tris buffer at $\mathrm{pH} 8.2$ (to give final concentrations of $1.0 \mathrm{~g} \mathrm{~L}^{-1}$ for G-HA and $1.1 \mathrm{~g} \mathrm{~L}^{-1}$ for P-HA) and equilibrated for 2 hours with a range of $\mathrm{Na}_{2}$-EDTA concentrations $(0,0.0005,0.0025$, $0.01,0.025$ and $0.05 \mathrm{M}$ ). Samples were analysed by SEC-ICP-MS to determine the concentrations of $\mathrm{Cu}$ complexes formed with EDTA, Tris and HA; all samples had $\mathrm{Na}_{2}-$ EDTA added exactly 2 hours before the start of their chromatographic runs. The proportion of EDTA-extractable $\mathrm{Cu}$ was calculated as the amount of ${ }^{65} \mathrm{Cu}$ removed from the HA complexes by EDTA divided by the total ${ }^{65} \mathrm{Cu}$ added to the system. Estimation of $\mathrm{Cu}$ recovery from the chromatographic process is discussed in Section 2.5 and the procedure for chromatograph integration is discussed in Section 3.2.

\subsection{Isotopically exchangeable $\mathrm{Cu}$}

153 Isotopic exchange kinetics and E-values for $\mathrm{Cu}\left(\mathrm{M}_{\mathrm{E}-\mathrm{HA}}\right)$ were determined for G-HA $\left(4.0 \mathrm{~g} \mathrm{~L}^{-1}\right)$ and P-HA ( $\left.4.4 \mathrm{~g} \mathrm{~L}^{-1}\right)$ solutions previously incubated for 40 days with a spike prepared from a 
$155 \mathrm{Cu}$ ICP-MS standard solution of $240 \mu \mathrm{g} \mathrm{L} \mathrm{L}^{-1}$ (natural isotopic abundance). Immediately 156 following further dilution with Tris buffer, the samples were spiked with sufficient enriched $157{ }^{65} \mathrm{Cu}$ solution to give measureable increases in ICP-MS signal. The final concentration of 158 added ${ }^{65} \mathrm{Cu}$ was $118.0 \mu \mathrm{g} \mathrm{L}{ }^{-1}$. This may seem quite a high spike level for measurement of E159 value but to measure the fate of the spike isotope against background, given the high isotopic 160 abundance of ${ }^{65} \mathrm{Cu}(31 \%)$, requires a higher spike level than would be necessary for elements 161 with more minor isotopes. Furthermore, the mole ratio of HA-carboxyl groups:Cu was still 162 approximately 1000:1 after spiking suggesting only minor disruption to the existing labile $\mathrm{Cu}$ equilibrium. Finally, we also considered that the normal concerns associated with soil materials, such as surface precipitation of spike metal, probably did not apply to dissolved humic acid solutions. The spiked HA solutions were then analysed using SEC-ICP-MS following isotopic equilibration times between $35 \mathrm{~min}$ and 3 days to monitor the progressive mixing of the ${ }^{65} \mathrm{Cu}$ isotope with the pre-existing metal.

\subsection{Calibration and recovery of SEC-ICP-MS chromatograms}

Trace metal calibration in SEC-ICP-MS can present problems because it is unlikely that inorganic salt standards would survive transition of the SEC column given the $\mathrm{pH}$ of the mobile phase. A solution to this is to use HA as a carrier for the metal standards. Calibration standards were therefore prepared by adding known concentrations of $\mathrm{Cu} \quad\left(0,30,60 \mu \mathrm{g} \mathrm{L}^{-1}\right)$

173 from ICP-MS standard solutions to a solution of G-HA (2 $\left.\mathrm{g} \mathrm{L}^{-1} \mathrm{HA}\right)$. The entire chromatogram for the ${ }^{63} \mathrm{Cu}$ isotope was integrated and an integrated blank chromatogram (2 $\mathrm{g}$ $\mathrm{L}^{-1} \mathrm{G}-\mathrm{HA}$ without added metal) subtracted to generate a calibration for $\mathrm{Cu}$ as (integrated) counts per second (CPS) against metal concentration $\left(\mathrm{R}^{2} \geq 0.99\right)$. The total $\mathrm{Cu}$ concentration in the incubated HA solutions (Section 2.4) was calculated using this 'standard addition' calibration. An alternative measurement of the total metal concentration was also made on dilutions of the HA solutions in a matrix of 0.005 M EDTA using 'direct aspiration' into the

180 ICP-MS. Recovery of metal through the SEC column was calculated by comparing the total $181 \mathrm{Cu}$ concentration measured using these two approaches.

\subsection{Time-dependent $\mathrm{Cu}$ isotope adsorption by humic acid}

184 The extent of movement of spike isotope from the non-HA phase (mainly Tris complexes) 185 into HA-complexed forms, as a function of contact time, was modelled using an adapted 
equation originally developed to describe the degree of mixing of radioactive isotopes with total soil metal pools (Sinaj et al., 1999), Eq.1.

$$
\mathrm{P}_{(\mathrm{t})}=\mathrm{P}_{(1)}\left[\mathrm{t}+\mathrm{P}_{(1)}{ }^{1 / \mathrm{n}}\right]^{-\mathrm{n}}+\mathrm{P}_{(\mathrm{M})}
$$

In this application $\mathrm{P}$ is the proportion of spiked ${ }^{65} \mathrm{Cu}$ in the non-humic section of the chromatogram (Tris complexes) at a specified time (t) or after $1 \mathrm{~min}(1)$, and $\mathrm{n}$ is an empirical constant; $\mathrm{P}_{(\mathrm{M})}$ is the value of $\mathrm{P}_{(\mathrm{t})}$ at infinite time. The constants $\mathrm{P}_{(1)}, \mathrm{P}_{(\mathrm{M})}$ and $\mathrm{n}$ were optimized by minimizing the residual standard deviation (RSD) between the measured and modelled values of $\mathrm{P}_{(\mathrm{t})}$ using the Solver function in Microsoft Excel.

\subsection{Calculation and prediction of $\mathrm{Cu}$ E-values}

The isotopic ratio of Tris-complexed $\mathrm{Cu}$ was used to calculate E-values in the presence of humic acid $\left(\mathrm{Cu}_{\mathrm{E}-\mathrm{HA}}\right)$. The calculation was adapted from Gabler et al. (1999), and is shown in Eq. 2 where ${ }^{65} \mathrm{Cu}$ is used as the spike isotope and ${ }^{63} \mathrm{Cu}$ is solely from native sources:

$$
\mathrm{Cu}_{\mathrm{E}-\mathrm{HA}}=\left(\frac{\mathrm{Cu}_{\mathrm{HA}}}{\mathrm{W}}\right)\left(\frac{\mathrm{C}_{\mathrm{spk}} \mathrm{V}_{\mathrm{spk}}}{\mathrm{Cu}_{\mathrm{spk}}}\right)\left(\frac{{ }^{65} \mathrm{IA}_{\mathrm{spk}}{ }^{63}{ }^{63} \mathrm{I}_{\mathrm{spk}} \mathrm{R}_{\mathrm{ss}}}{{ }^{63} \mathrm{IA}_{\mathrm{HA}} \mathrm{R}_{\mathrm{ss}}{ }^{-{ }^{65}}{ }^{\mathrm{IA}} \mathrm{A}_{\mathrm{HA}}}\right)
$$

In Eq. $2 \mathrm{Cu}_{\mathrm{HA}}$ and $\mathrm{Cu}_{\text {spk }}$ is the average atomic mass of $\mathrm{Cu}$ in the (unspiked) $\mathrm{HA}$ solution and the enriched ${ }^{65} \mathrm{Cu}$ spike solution respectively, $\mathrm{W}$ is the weight of humic acid $(\mathrm{kg}), \mathrm{C}_{\mathrm{spk}}$ is the gravimetric concentration of $\mathrm{Cu}$ in the spike solution, $\mathrm{V}_{\mathrm{spk}}$ is the volume of spike added (L), IA is the molar isotopic abundance of ${ }^{65} \mathrm{Cu}$ or ${ }^{63} \mathrm{Cu}$ in the spike solution or unspiked HA solution, and $\mathrm{R}_{\mathrm{ss}}$ is the isotopic ratio of ${ }^{65} \mathrm{Cu}$ to ${ }^{63} \mathrm{Cu}$ in the spiked HA solution measured in the 'non-humic' section of the chromatogram.

The change in $\% \mathrm{Cu}_{\mathrm{E}-\mathrm{HA}}$ with time, following addition of the spike, was described by an empirical equation (Eq. 3) adapted from Eq.1.

$$
\% \mathrm{Cu}_{\mathrm{E}-\mathrm{HA}}=100\left[1-\mathrm{K}\left(\mathrm{t}+\mathrm{K}^{\frac{1}{n}}\right)^{-\mathrm{n}}\right]
$$

In Eq. 3, $\mathrm{K}$ and $\mathrm{n}$ are empirical constants that determine the shape of the relationship. The values of K and $\mathrm{n}$ were optimized using the Solver function in Microsoft Excel to minimize the residual standard deviation (RSD) between the modelled and measured values of $\% \mathrm{Cu}_{\mathrm{E}}$ 
212 HA. The main feature of this equation is that it successfully describes an initially steep

213 increase in the value of $\% \mathrm{Cu}_{\mathrm{E}-\mathrm{HA}}$, from zero, followed by sharp change in slope and a very

214 slow continuous increase with time $(\mathrm{t})$ thereafter, reaching a final asymptote of $100 \%$ at

215 infinite time (100\% to 6 decimal places at $\left.10^{200} \mathrm{~min}\right)$.

\section{3. Results and discussion}

\section{$217 \quad 3.1 \quad$ General characterization of $\mathrm{Cu}$ on dissolved humic acid}

218 Chromatograms of the two non-humic complexes of $\mathrm{Cu}$ (EDTA and Tris) used in this study 219 are shown in Fig. 1. The EDTA complex emerged at about $16 \mathrm{~min}$ and consisted of a single 220 sharp peak with minor shoulders suggesting minimal $\mathrm{Cu}$ re-distribution due to Tris- $\mathrm{Cu}$ complex formation in the eluent. The Tris- $\mathrm{Cu}$ complex peak emerged at about 19 min and, by contrast, was broad with a long tail, suggesting some $\mathrm{Cu}$ re-distribution during transition through the column, possibly due to Tris $(0.1 \mathrm{M})$ in the flowing eluent.

Chromatograms showing both HAs (G-HA and P-HA) incubated with $\mathrm{Cu}$ for 40 days, eluted in a Tris buffer, are shown in Fig. 2. The distribution of $\mathrm{Cu}$ between HA and Tris complexes is reasonably clear, with larger organic species having a shorter residence time. The first sharp peak $($ c. $7 \mathrm{~min}$ ) is the excluded fraction. Although this peak probably consists mainly of $\mathrm{HA}-\mathrm{Cu}$ complexes larger than $300,000 \mathrm{Da}$ it may also include inorganic nanoparticles; this is discussed further in section 3.4. Subsequently, a broad peak (7.5 - 13 min) was seen in all chromatograms reflecting the distribution of molecular masses of the HA but also probably arising from various forms of HA interaction with the column matrix, either involving hydrophobic aromatic functional groups (Asakawa et al., 2011) or charged surfaces, leading to changes in retention time (Chin and Gschwend, 1991; Jackson et al., 2005; Pelekani et al., 1999). Copper complexes were eluted over 20 mins with a diffuse peak at 16-19 mins possibly a result of active $\mathrm{Cu}$-Tris complex formation during elution. A comparison with Fig. 1 suggests that $\mathrm{Cu}$-Tris complexes were eluted earlier than was seen in Fig. 1 - although still mainly after the $\mathrm{Cu}-\mathrm{HA}$ complex elution. This is not unexpected because the origin of $\mathrm{Cu}$ Tris complexes in Fig. 2 must have been labile $\mathrm{Cu}$ stripped out from the HA during its comparatively rapid transit through the SEC column due to its greater molecular size. McPhail and Goodman (1984) studied a Cu-enzyme-Tris system, analysing the spectra of $\mathrm{Cu}$ 
complexes with bovine superoxide dismutase and $\mathrm{Cu}$-Tris complexes. Their results confirmed the presence of Tris- $\mathrm{Cu}$ complexes at $\mathrm{pH} 8.0$, causing the authors to advise caution when using Tris as an eluent in chromatographic work. In our application, however, Tris complex formation with $\mathrm{Cu}$ is actually 'required' as it enables determination of the isotopic ratio of the labile metal fraction (see Section 3.4). Total $\mathrm{Cu}$ recovery was reasonably close to $100 \%$ for both G-HA (103\%) and P-HA (94\%).

\subsection{Integration of Cu chromatograms}

As shown in Fig. 3, the distinction between HA- and Tris-bonded forms of $\mathrm{Cu}$ was quite poor. To calculate the E-value for $\mathrm{Cu}\left(\mathrm{Cu}_{\mathrm{E}-\mathrm{HA}}\right)$ on $\mathrm{HA}$ it was necessary to integrate the ${ }^{65} \mathrm{Cu}$ and ${ }^{63} \mathrm{Cu}$ peaks representing the $\mathrm{Cu}$-Tris complex; from this a labile ${ }^{65} \mathrm{Cu} /{ }^{63} \mathrm{Cu}$ isotopic ratio could then be calculated to compare with the HA-bound $\mathrm{Cu}$ isotopes. To avoid using an arbitrary division between $\mathrm{HA}-\mathrm{Cu}$ and Tris- $\mathrm{Cu}$ a test was undertaken to establish the effect of progressively integrating from both ends of the chromatogram. The G-HA solution was spiked with a ${ }^{65} \mathrm{Cu}$ enriched solution and equilibrated for 72 hours before analysis (Fig. 3). Ten points were selected, spanning the chromatogram between 7 and 23 min. Cumulative integration of the ${ }^{65} \mathrm{Cu}$ and ${ }^{63} \mathrm{Cu}$ signals was undertaken in both directions along the time axis, i.e. from high molecular weight (MW) to low MW (5 min to $25 \mathrm{~min}$ ), and vice versa, and the isotope ratio ${ }^{65} \mathrm{Cu} /{ }^{63} \mathrm{Cu}$ for the cumulative signal was calculated. Complete isotopic mixing of the ${ }^{65} \mathrm{Cu}$ spike within $72 \mathrm{~h}$ would have produced a ${ }^{65} \mathrm{Cu} /{ }^{63} \mathrm{Cu}$ ratio of 2.181 (solid horizontal line in Fig. 3). However, when integrating from the high MW end (the start) of the chromatogram isotopic ratios before $13.3 \mathrm{~min}$ (mainly $\mathrm{HA}$-bound $\mathrm{Cu}$ ) were much lower than 2.181. Similarly, when integrating backwards, from the end of the chromatogram, the ${ }^{65} \mathrm{Cu} /{ }^{63} \mathrm{Cu}$ ratio (Tris complexed forms) was greater than 2.181. There was, therefore, incomplete mixing of the ${ }^{65} \mathrm{Cu}$ spike with $\mathrm{Cu}$ held by the dissolved HA which appears to prove the existence of non-labile forms of $\mathrm{Cu}$ bound to dissolved humic acid. Thus, only isotopic ratios calculated after $16.3 \mathrm{~min}$, associated with labile Tris-Cu complexes (Rss in Eq. 2), were used in the calculation of $\mathrm{Cu}_{\mathrm{E}-\mathrm{HA}}$ in $\mathrm{HA}$. 


\subsection{EDTA extraction of $\mathrm{Cu}$ on humic acid}

273 Concentrations of weak acid functional groups on HA were $5.5 \times 10^{-3} \mathrm{M}$ and $7.7 \times 10^{-3} \mathrm{M}$ for 274 the G-HA and P-HA solutions respectively calculated from the total acidity as measured by 275 Marshall et al. (1995). Concentrations of EDTA carboxyl groups in the extracting solutions 276 ranged from $2 \times 10^{-3} \mathrm{M}$ (in $0.0005 \mathrm{M}$ EDTA) to $0.2 \mathrm{M}$ (in $0.05 \mathrm{M}$ EDTA). Therefore, it is 277 reasonable to expect that the highest concentrations of EDTA should have enabled complex 278 formation with all labile $\mathrm{Cu}$ whereas at the two lowest EDTA concentrations HA should have 279 been a strong competitor for $\mathrm{Cu}$ binding. Figure 4 shows ${ }^{63} \mathrm{Cu}$ and ${ }^{65} \mathrm{Cu}$ chromatograms for $280 \mathrm{P}-\mathrm{HA}$ in $0.0005 \mathrm{M}$ and $0.05 \mathrm{M}$ EDTA. It should be noted that the (native) ${ }^{63} \mathrm{Cu}$ present 281 originates solely from residual $\mathrm{Cu}$ in the 'purified' HA which has either resisted acid dialysis 282 during the preparation of the HA or been adsorbed from distilled water during the extended 283 dialysis against water used to remove residual acid (Marshall et al., 1995). The ${ }^{65} \mathrm{Cu}$ was equilibrated in the HA solutions for 40 days prior to extraction for $2 \mathrm{~h}$ with EDTA. A decrease in ICP signal was observed for both isotopes bound to HA, with an increase in the EDTA-bound metal peak, as the EDTA concentration was increased. However, even though it might be expected that $0.05 \mathrm{M}$ EDTA would be able to complex all $\mathrm{Cu}$ in the system, a significant proportion of $\mathrm{Cu}(>40 \%)$, for both residual (e.g. $\left.{ }^{63} \mathrm{Cu}\right)$ and spiked $\left({ }^{65} \mathrm{Cu}\right)$ isotopes, remained bound to both HAs. This provides further evidence of non-labile $\mathrm{Cu}$ bound to humic acid. The diffuse peak representing Tris-Cu complexes (c. $15-19$ min) also diminished, as the EDTA concentration increased. The EDTA-Cu peak shifted to a longer elution time at higher EDTA concentrations which may indicate changes in speciation during elution within the SEC column.

There was a clear increase in \%EDTA extractable $\mathrm{Cu}$ when EDTA concentration was above $0.01 \mathrm{M}$ (Fig. 5). A significant change in \%EDTA-extractable $\mathrm{Cu}$ with $\mathrm{HA}-\mathrm{Cu}$ equilibration time (40 or 160 days) was observed while residual $\mathrm{Cu}$, present within the $\mathrm{HA}$, was least extractable. This indicates that time-dependent fixation of the added metal occurred during incubation (40 and 160 days) and that the residual metal (present in the purified HA) was held in the most stable form. An ageing effect for metals bound to humic substances has also been reported in other studies (Burba, 1994; Rate et al., 1993) and two hypotheses have been proposed to explain the phenomenon. Choppin and Clark (1991) suggested that there was movement of metals from weak binding sites to strong sites when the macromolecular 
structure of HA opens as a result of charge repulsion between ionized acidic functional groups enabling the aqueous solute to access otherwise hydrophobic domains within the DOM (McCarthy et al., 1989). An alternative theory, known as the 'thermodynamic' hypothesis (Cabaniss, 1990; Rate et al., 1993) is that it simply takes time for metals such as $\mathrm{Cu}, \mathrm{Zn}$ and $\mathrm{Pb}$ to migrate to the strongest binding sites while being effectively impeded by (temporary) binding to weaker sites.

For both types of $\mathrm{HA}, \mathrm{Cu}$ was strongly bound, with only $60 \%$ extracted in $0.05 \mathrm{M}$ EDTA. It has been suggested that $\mathrm{Cu}$ binding to soil $\mathrm{HA}$ is stronger than to peat HA (Sahu and Banerjee, 1990), but the results in Fig. 5 suggest the reverse. However, this may be a consequence of the lower concentrations of residual $\mathrm{Cu}$ in P-HA $\left(21.6 \mathrm{mg} \mathrm{kg}^{-1}\right)$ than that in G-HA (91.0 $\mathrm{mg} \mathrm{kg}^{-1}$ ), perhaps resulting in greater availability of strong binding sites in P-HA.

\subsection{Isotopically exchangeable $\mathrm{Cu}$ on humic acid}

Chromatograms of ${ }^{63} \mathrm{Cu}$ and ${ }^{65} \mathrm{Cu}$ in G-HA and P-HA solutions are shown in Fig. 6a; the ${ }^{63} \mathrm{Cu}$-enriched HA solutions were incubated for 40 days before spiking with ${ }^{65} \mathrm{Cu}$ and equilibrating for a further 3 days. For both HAs the distribution of the spiked ${ }^{65} \mathrm{Cu}$ appeared to coincide with that of the ${ }^{63} \mathrm{Cu}$. Closer investigation by comparing the isotopic ratio $\left({ }^{65} \mathrm{Cu} /{ }^{63} \mathrm{Cu}\right)$ in three regions of the HA chromatograms that were free from the influence of Tris complexes (6 - $7.5 \mathrm{~min} ; 7.5$ - $8.6 \mathrm{~min}$ and 8.6 - $10.1 \mathrm{~min}$ ) confirmed that there was no significant difference between the three fractions $(\mathrm{P}>0.1)$. Comparison of isotopic ratios in the same three sections of chromatograms for non-spiked samples also showed no change. This suggests that (i) added $\mathrm{Cu}$ was distributed across the HA molecular size range in the same proportion as native $\mathrm{Cu}$ and (ii) there was no confounding effect of metal spiking such as conformational changes in the humic structure. One of the regions within the HA section of the chromatogram (6 - $7.5 \mathrm{~min})$ includes the excluded fraction (first sharp peak in Fig. 6a) which may include inorganic nanoparticles along with large MW HA molecules. We tested this by comparing the $\mathrm{Cu}$ isotopic ratio ${ }^{65} \mathrm{Cu} /{ }^{63} \mathrm{Cu}$ and found that it was very similar in both the excluded and non-excluded sections of the chromatograph. However, we also measured $\mathrm{Pb}$ and $\mathrm{Zn}$ (data not shown) and found that there was a significant change in the elemental ratios $(\mathrm{Pb} / \mathrm{Cu}$ and $\mathrm{Zn} / \mathrm{Cu})$ between the excluded and non-excluded sections suggesting metal binding particles other than HA. Thus it appears that while there may be inorganic 
nanoparticles (containing $\mathrm{Zn}$ and $\mathrm{Pb}$ ) in the excluded fraction there is also $\mathrm{HA}$ and the $\mathrm{Cu}$ is predominantly held in the latter.

For both G-HA and P-HA, Eq. 1 described the distribution of the ${ }^{65} \mathrm{Cu}$ spike between HA and Tris complexes very closely (Fig. 6b). The optimized constants in Eq. 1 for G-HA were P(1) $=0.86, \mathrm{P}(\mathrm{M})=0.48, \mathrm{n}=0.29$ and for $\mathrm{P}-\mathrm{HA}$ they were $\mathrm{P}(1)=0.99, \mathrm{P}(\mathrm{M})=0.21, \mathrm{n}=0.17$. Changes in the $\mathrm{Cu}$ isotopic ratio of Tris complexes and HAs, as a function of time after spiking with ${ }^{65} \mathrm{Cu}$, are shown in Fig. 6c. The difference between the ratio of ${ }^{65} \mathrm{Cu} /{ }^{63} \mathrm{Cu}$ in Tris complexes and that in the HA phase of the chromatogram implies the existence of non-labile $\mathrm{Cu}$ in $\mathrm{HA}$. The flat trends of both curves after $24 \mathrm{hr}$ suggest a progressively slower approach to an eventual equilibrium. Isotopic ratios for Tris-complexed $\mathrm{Cu}$ were used to calculate $\mathrm{Cu}_{\mathrm{E}}$ $\mathrm{HA}$ according to Eq. 2. Lability (\%Cu $\left.\mathrm{U}_{\mathrm{E}-\mathrm{HA}}\right)$ was then calculated by dividing $\mathrm{Cu}_{\mathrm{E}-\mathrm{HA}}\left(\mathrm{mg} \mathrm{kg}^{-1}\right)$ by total $\mathrm{Cu}$ concentration measured after SEC elution. Values of $\% \mathrm{Cu}_{\mathrm{E}-\mathrm{HA}}$ after 2-3 days (4872 hours) were very close to the value of \%EDTA extractable measured in 0.05 M EDTA extracts of the HAs spiked with ${ }^{65} \mathrm{Cu}$ and incubated for 40 days (Fig. 5). The lability of $\mathrm{Cu}$ in G-HA was slightly greater than that in P-HA. Values of $\% \mathrm{Cu}_{\mathrm{E}-\mathrm{HA}}$ increased with time (Fig. 7) suggesting the spike isotope gradually accessed more binding sites within the HA structure. The increase in $\% \mathrm{Cu}_{\mathrm{E}-\mathrm{HA}}$ in the first hour was approximately $20 \%$ for G-HA and $10 \%$ for PHA. There was then a gradual increase in the apparent E-value, implying a slow reaction with stronger binding sites, tending eventually towards $100 \%$ at infinite time when theoretically all the spiked isotopes were fully mixed with the incubated metals. A visual appraisal of Fig. 7 suggests a reasonably stable value of $\% \mathrm{Cu}_{\mathrm{E}-\mathrm{HA}}$ was obtained $>24 \mathrm{hr}$ after spiking. Although the fitted trend line (Eq. 3) eventually reaches an asymptote at $100 \%$, the data suggests a clear distinction between labile and non-labile forms of HA-bound $\mathrm{Cu}$. Therefore, to avoid fixation of isotopes on HAs, whilst allowing sufficient time for metal to access all isotopically exchangeable binding sites, it appears prudent to use an equilibrium time of 24 to $48 \mathrm{hr}$ to determine apparent $\mathrm{Cu}_{\mathrm{E}-\mathrm{HA}}$. The optimized values of $\mathrm{K}$ and $\mathrm{n}$ in Eq. 3 are presented in Table 1 .

It is reasonable to ask whether $\mathrm{Cu}$-Tris complex formation might involve loss of 'non-labile' $\mathrm{Cu}$ from the $\mathrm{HA}$ - rather than only labile forms, on which the analysis and interpretation presented depends. A comparison with EDTA is useful in this context. A study by Nagaj et al., (2013) cites a range of published $\left(\log _{10}\right)$ stability complexes for the $1: 1 \mathrm{Cu}$-Tris complex, ranging from $3.8-5.8$. These contrast markedly with the (much larger) Cu-EDTA stability 
constant $\left(\log _{10} \mathrm{~K}=18.8\right)$ and Fig. 1 shows little or no evidence of $\mathrm{Cu}$-EDTA dissociation by

368 Tris in the eluent - ie there is a single sharp Cu-EDTA peak. That suggests that Tris cannot extract $\mathrm{Cu}$ from the EDTA complex. Turning to EDTA extraction of $\mathrm{Cu}$ from HA (Fig. 5) there was a remarkably flat response in \% Cu extracted with increase in EDTA concentration even up to an EDTA concentration of 0.05 M. That suggests that even EDTA cannot easily extract non-labile $\mathrm{Cu}$ from $\mathrm{HA}$ - and so we suggest that Tris is very unlikely to have much impact on non-labile HA-Cu complexes. We think this provides some evidence that the nonlabile $\mathrm{Cu}$ phase in the HA was largely intact in the presence of Tris and this validates the calculation of E-values.

\subsection{Implications for geochemical modelling of humic binding of $\mathrm{Cu}$}

378 Geochemical models, such as WHAM VII and NICA-Donnan, describe cation and proton 379 binding to humic substances. They are parameterized from large datasets (248 for Model VII, 380 Tipping et al., 2011). Most of these data originate from potentiometric studies of humic and fulvic acids, titrated over quite short periods of time with metal salts; typically less than 1 hour is allowed for equilibration. Thus the formation of non-labile metal complexes is not generally considered (e.g. Benedetti et al., 1996; Christl and Krnetzschmar, 2001; Fitch et al., 1986). A model parameterised in this way may reliably predict HA-metal binding over the short term but is at risk of underestimating the degree of organic complex formation in fieldcollected samples of river water or soil solutions, in which non-labile humic-bound metal is likely to be present. In this context, the models may over-predict the free ion activity and under-estimate the organic bound fraction. Only a few studies have investigated how the presence of a non-labile humic-bound fraction may affect model predictions of speciation in natural water. Weng et al. (2002) applied WHAM Model VI to predict metal complexation with DOM from total trace metal concentration in soil solution. They observed overestimation of free metal ion activity and this was more significant for $\mathrm{Cu}$ and $\mathrm{Pb}$ than for $\mathrm{Ni}, \mathrm{Zn}$ and $\mathrm{Cd}$. By contrast, discrepancies are not likely to be observed when measuring and modelling a system in which organic matter has been purified and trace metals freshly added. For example, Cheng and Allen (2006) titrated 'purified' natural organic matter from lake and river water with $\mathrm{Zn}$, in which the residual trace metals were negligible compared to the amount that was added, and found good agreement between the measured and modelled (WHAM VI) estimates of free $\mathrm{Zn}$ ion activity in $\mathrm{pH}$ neutral samples. 
399 It is difficult to assess the extent to which a non-labile humic-bound metal fraction would 400 affect model prediction generally as other factors are likely to influence the prediction of free 401 metal ion activity. There is still uncertainty in measuring free ion activity at low 402 concentrations by Donnan or resin exchange techniques (Degryse et al., 2009) or using ISEs 403 (Fish and Brassard, 1997; Westall et al., 1979). There is also likely to be an effect of pH on 404 the proportions of labile and non-labile metal, as widely found for soils, and the proportion of 405 metal fixed will probably depend on its level of occupancy of available HA groups. WHAM 406 VII allows for a small number of very strongly bonding tri-dentate group configurations 407 which are required to explain strong metal binding observed at low concentrations. Tipping 408 (1998) estimated that the proportion of groups on HA forming tridentate complexes was only 4090.065 and within the model only $0.9 \%$ of these form the strongest category of complexes with 410 metals. With a default (WHAM VII) site density on HA of $3.4 \times 10^{-3} \mathrm{~mol} \mathrm{~g}^{-1}$, the number of 411 tridentate sites forming the strongest bonds is therefore estimated as $2 \times 10^{-6} \mathrm{~mol} \mathrm{~g}^{-1}$. The 412 concentrations of non-labile $\mathrm{Cu}$ measured were $1.1 \times 10^{-6}$ and $0.6 \times 10^{-6} \mathrm{~mol} \mathrm{~g}^{-1}$ for G-HA 413 and P-HA respectively. Of course, it is not possible to demonstrate a causal association 414 between these measured values and what is a fitted model binding capacity term. It must also 415 be remembered that the high affinity tridentate sites postulated within the WHAM VII model 416 are also implicitly regarded as reversible (labile).

\section{4. Conclusions}

418 Time-dependent non-labile $\mathrm{Cu}$ binding to dissolved humic acids from grassland and peat soils 419 was observed using EDTA extraction and isotopic dilution following speciation by LC-ICP420 MS. Results indicated that the proportion of non-labile $\mathrm{Cu}$ on HAs can be $40-50 \%$ within the range of metal amendments used. It is difficult to draw general conclusions regarding the likely impact of non-labile metal on geochemical speciation model predictions. Deviations from model predictions due solely to this factor will depend critically on the history of HAmetal contact, speciation-controlling factors such as $\mathrm{pH}$ and the ratio of metal to humic binding capacity in the system under study. However, it is suggested that the assumption made in geochemical speciation models that all metals bound to dissolved humic acid are labile (reversibly bound), needs refinement and testing. It would also be interesting to extend the approach used here to include fulvic acid which is probably more active in determining trace metal mobility but may differ from $\mathrm{HA}$ in its capacity to bind $\mathrm{Cu}$ in a non-labile form. 
431 ACKNOWLEDGEMENTS:

432 The authors thank the University of Nottingham for providing research funding. 
434 Asakawa, D., Iimura, Y., Kiyota, T., Yanagi, Y., Fujitake, N., 2011. Molecular size 435 fractionation of soil humic acids using preparative high performance size-exclusion 436 chromatography. Journal of Chromatography A 1218, 6448-6453.

437 Benedetti, M.F., VanRiemsdijk, W.H., Koopal, L.K., Kinniburgh, D.G., Gooddy, D.C., Milne, 438 C.J., 1996. Metal ion binding by natural organic matter: From the model to the field. 439 Geochim. Cosmochim. Acta 60, 2503-2513.

440 Burba, P., 1994. Labile/inert metal species in aquatic humic substances - an ion-exchange 441 study. Fresenius J. Anal. Chem. 348, 301-311.

442 Cabaniss, S.E., 1990. $\mathrm{pH}$ and ionic-strength effects on nickel fulvic-acid dissociation kinetics. 443 Environ. Sci. Technol. 24, 583-588.

444 Cheng, T., Allen, H.E., 2006. Comparison of zinc complexation properties of dissolved 445 natural organic matter from different surface waters. Journal of Environmental Management $44680,222-229$.

447 Chin, Y.P., Gschwend, P.M., 1991. The abundance, distribution, and configuration of 448 porewater organic colloids in recent sediments. Geochimica Et Cosmochimica Acta 55, 13094491317.

450 Choppin, G.R., Clark, S.B., 1991. The kinetic interactions of metal-ions with humic acids. 451 Mar. Chem. 36, 27-38.

452 Christla, I., Kretzschmar, R., 2001. Interaction of copper and fulvic acid at the hematite-water 453 interface. Geochim. Cosmochim. Acta 65, 3435-3442. in soils: concepts, methodologies, prediction and applications - a review. Eur. J. Soil Sci. 60, 590-612.

Fish, S.J., Brassard, P., 1997. Dialysis Membrane to Prevent Cadmium Ion Specific Electrode fouling. Talanta 44, 939-945.

460 Response characteristics of the $\mathrm{Cu}$ (II) ion-selective electrode and ligand concentration effects. 461 Organic Geochemistry 9, 109-116.

462 Gabler, H.E., Bahr, A., Heidkamp, A., Utermann, J., 2007. Enriched stable isotopes for determining the isotopically exchangeable element content in soils. Eur. J. Soil Sci. 58, 746757.

465 Gabler, H.E., Bahr, A., Mieke, B., 1999. Determination of the interchangeable heavy-metal 466 fraction in soils by isotope dilution mass spectrometry. Fresenius J. Anal. Chem. 365, 409467414.

468 Jackson, B.P., Ranville, J.F., Bertsch, P.M., Sowder, A.G., 2005. Characterization of 469 colloidal and humic-bound $\mathrm{Ni}$ and $\mathrm{U}$ in the "dissolved" fraction of contaminated sediment 470 extracts. Environ. Sci. Technol. 39, 2478-2485. 
Kinniburgh, D.G., van Riemsdijk, W.H., Koopal, L.K., Borkovec, M., Benedetti, M.F., Avena, M.J., 1999. Ion binding to natural organic matter: competition, heterogeneity, stoichiometry and thermodynamic consistency. Colloids and Surfaces a-Physicochemical and Engineering Aspects 151, 147-166.

475

476

477

478

479

480

481

482

483

484

485

486

487

488

489

490

491

492

493

494

495

496

497

498

499

500

501

502

503

504

505

Kozai, N., Ohnuki, T., Iwatsuki, T., 2013. Characterization of saline groundwater at Horonobe, Hokkaido, Japan by SEC-UV-ICP-MS: Speciation of uranium and iodine. Water Res. 47, 1570-1584.

Laborda, F., Ruiz-Begueria, S., Bolea, E., Castillo, J.R., 2011. Study of the size-based environmental availability of metals associated to natural organic matter by stable isotope exchange and quadrupole inductively coupled plasma mass spectrometry coupled to asymmetrical flow field flow fractionation. J. Chromatogr. A 1218, 4199-4205.

Liu, G.L., Cai, Y., 2010. Complexation of arsenite with dissolved organic matter Conditional distribution coefficients and apparent stability constants. Chemosphere 81, 890-896.

Liu, G.L., Fernandez, A., Cai, Y., 2011. Complexation of Arsenite with Humic Acid in the Presence of Ferric Iron. Environ. Sci. Technol. 45, 3210-3216.

Lofts, S., Tipping, E., 2011. Assessing WHAM/Model VII against field measurements of free metal ion concentrations: model performance and the role of uncertainty in parameters and inputs. Environ. Chem. 8, 501-516.

Lombi, E., Hamon, R.E., McGrath, S.P., McLaughlin, M.J., 2003. Lability of Cd, Cu, and Zn in polluted soils treated with lime, beringite, and red mud and identification of a non-labile colloidal fraction of metals using isotopic techniques. Environ. Sci. Technol. 37, 979-984.

Ma, Y.B., Lombi, E., Nolan, A.L., McLaughlin, M.J., 2006. Determination of labile Cu in soils and isotopic exchangeability of colloidal Cu complexes. Eur. J. Soil Sci. 57, 147-153.

Marshall, S.J., Young, S.D., Gregson, K., 1995. Humic-acid proton equilibria - a comparison of two models and assessment of titration error. Eur. J. Soil Sci. 46, 471-480.

McCarthy, J.F., Roberson, L.E., Burrus, L.W., 1989. Association of benzo(a)pyrene with dissolved organic matter: Prediction of Kdom from structural and chemical properties of the organic matter. Chemosphere 19, 1911-1920.

McPhail, D.B., Goodman, B.A., 1984. Tris buffer--a case for caution in its use in coppercontaining systems. Biochemical Journal 221, 559-560.

Nagaj, J., Stokowa-Sołtys, K., Kurowska, E., Frączyk, T., Jeżowska-Bojczuk, M., Bal, W. 2013.

Revised coordination model and stability constants of $\mathrm{Cu}(\mathrm{II})$ complexes of Tris buffer. Inorg. Chem. 52, 13927-13933

Nolan, A.L., Ma, Y.B., Lombi, E., McLaughlin, M.J., 2009. Speciation and Isotopic Exchangeability of Nickel in Soil Solution. J. Environ. Qual. 38, 485-492.

Pelekani, C., Newcombe, G., Snoeyink, V.L., Hepplewhite, C., Assemi, S., Beckett, R., 1999. Characterization of natural organic matter using high performance size exclusion chromatography. Environ. Sci. Technol. 33, 2807-2813. 
510 Rate, A.W., McLaren, R.G., Swift, R.S., 1993. Response of copper (II) humic-acid 511 dissociation kinetics to factors influencing complex stability and macromolecular 512 conformation. Environ. Sci. Technol. 27, 1408-1414.

513 Sahu, S., Banerjee, D.K., 1990. Complexation Properties of Typical Soil and Peat Humic 514 Acids with Copper(II) and Cadmium(II). Int. J. Environ. Anal. Chem. 42, 35-44.

515 Schmitt, D., Muller, M.B., Frimmel, F.H., 2001. Metal distribution in different size fractions 516 of natural organic matter. Acta Hydrochim. Hydrobiol. 28, 400-410.

517 Schnitzer, M., Khan, S.U., 1972. Humic substances in the environment. M. Dekker, New 518 York.

519 Sinaj, S., Machler, F., Frossard, E., 1999. Assessment of isotopically exchangeable zinc in 520 polluted and nonpolluted soils. Soil Sci. Soc. Am. J. 63, 1618-1625.

521 Smolders, E., Brans, K., Foldi, A., Merckx, R., 1999. Cadmium fixation in soils measured by 522 isotopic dilution. Soil Sci. Soc. Am. J. 63, 78-85.

523 Tipping, E., 1998. Humic ion-binding model VI: An improved description of the interactions 524 of protons and metal ions with humic substances. Aquat. Geochem. 4, 3-48.

525 Tipping, E., 2002. Cation binding by humic substances. Cambridge, Cambridge.

526 Tipping, E., Lofts, S., Sonke, J.E., 2011. Humic Ion-Binding Model VII: a revised

527 parameterisation of cation binding by humic substances. Environ. Chem. 8, 225-235.

528 Weng, L.P., Temminghoff, E.J.M., Lofts, S., Tipping, E., Van Riemsdijk, W.H., 2002. 529 Complexation with dissolved organic matter and solubility control of heavy metals in a sandy 530 soil. Environ. Sci. Technol. 36, 4804-4810.

531 Westall, J.C., Morel, F.M.M., Hume, D.N., 1979. Chloride Interference in Cupric Ion 532 Selective Electrode Measurements. Anal. Chem. 51, 1792-1798.

533 Young, S.D., Tye, A., Carstensen, A., Resende, L., Crout, N., 2000. Methods for determining 534 labile cadmium and zinc in soil. Eur. J. Soil Sci. 51, 129-136. 
539 Table 1: Values of the parameterized model constants and RSD for Equations 1 and 3

\begin{tabular}{cccccc}
\hline Eq. 1 & G-HA & P-HA & Eq. 3 & G-HA & P-HA \\
\hline $\mathrm{P}_{(1)}$ & 0.86 & 0.99 & $\mathrm{~K}$ & 0.762 & 0.987 \\
$\mathrm{P}_{(\mathrm{M})}$ & 0.48 & 0.21 & $\mathrm{n}$ & 0.073 & 0.093 \\
$\mathrm{n}$ & 0.29 & 0.17 & & & \\
\hline RSD(prop.) & 0.009 & 0.005 & $\mathrm{RSD}(\%)$ & 4.83 & 1.52 \\
\hline
\end{tabular}

540

541

542 


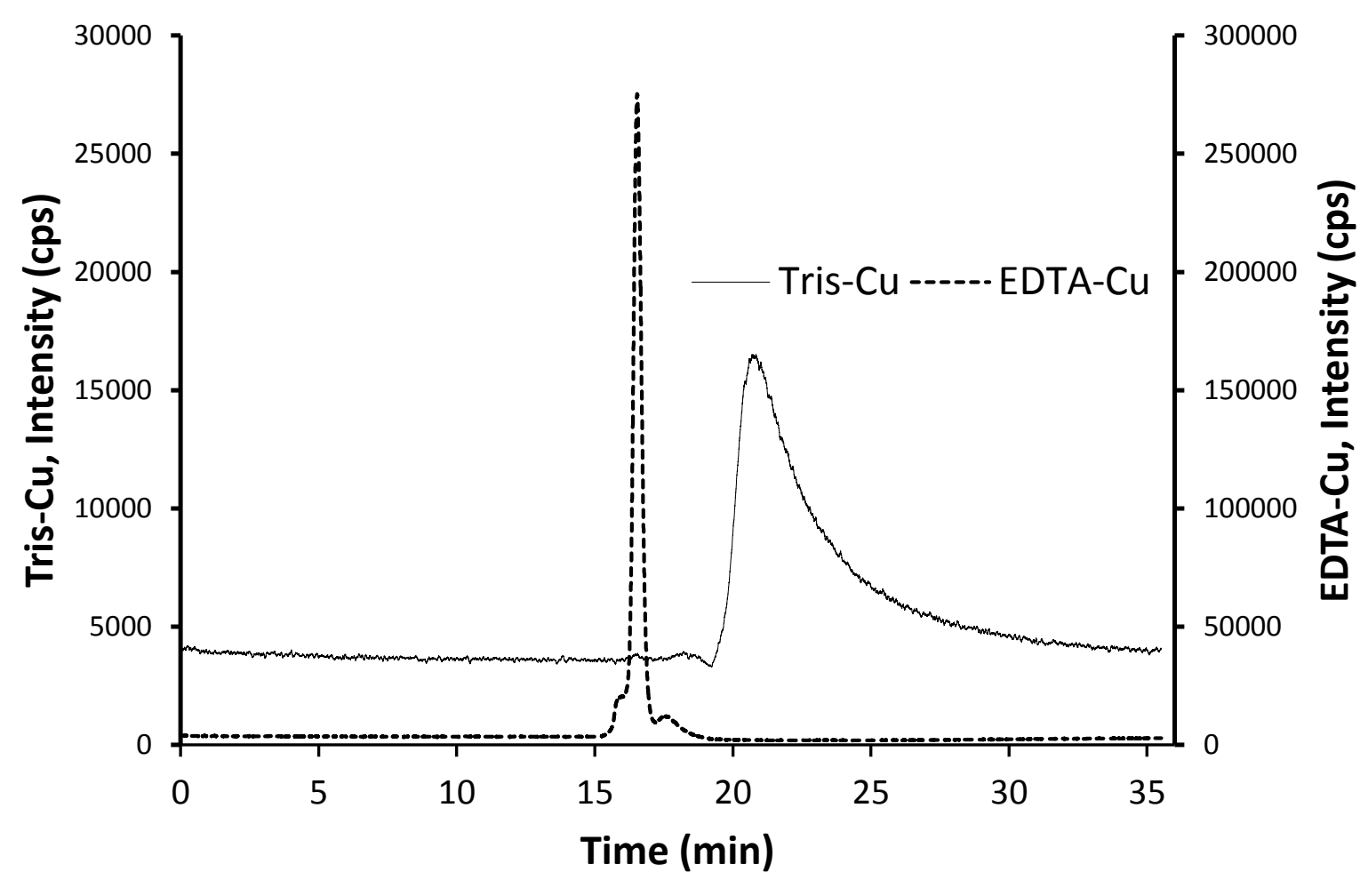

547 Figure 1. SEC-ICP-MS chromatograms of Tris-Cu (solid line) and EDTA-Cu (broken line)

548 complexes (0.1 M Tris eluent at $\mathrm{pH}$ 8.2). Samples containing $\mathrm{Cu}\left(25 \mu \mathrm{g} \mathrm{L}^{-1}\right)$ in $0.075 \mathrm{M}$ Tris 549 or $0.0125 \mathrm{M}\left(\mathrm{NH}_{4}\right)_{2}$-EDTA were equilibrated for $72 \mathrm{hr}$ prior to analysis. 


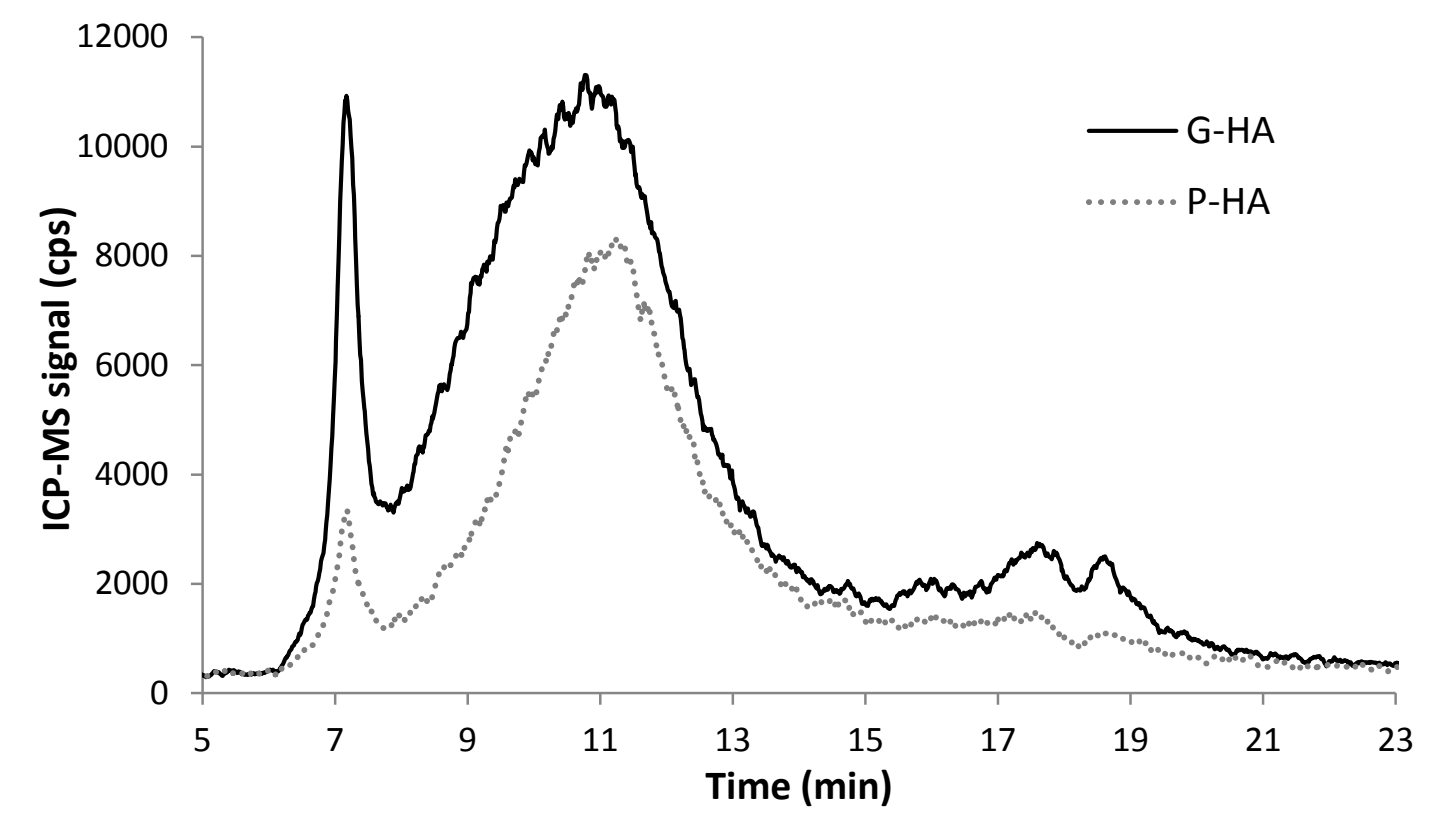

552

553 Figure 2: SEC-ICP-MS chromatograms of ${ }^{63} \mathrm{Cu}$ showing complex formation with grassland 554 soil humic acid (G-HA; $\left.1.0 \mathrm{~g} \mathrm{~L}^{-1}\right)$ and peat humic acid (P-HA; $\left.1.1 \mathrm{~g} \mathrm{~L}^{-1}\right)$ at $\mathrm{pH} 7.0$. Both 555 humic acids were incubated with $\mathrm{Cu}$ (natural isotopic abundance) for 40 days. The final $\mathrm{Cu}$ 556 concentrations were $151 \mathrm{mg} \mathrm{kg}^{-1}$ and $81.6 \mathrm{mg} \mathrm{kg}^{-1}$ for G-HA and P-HA respectively. 


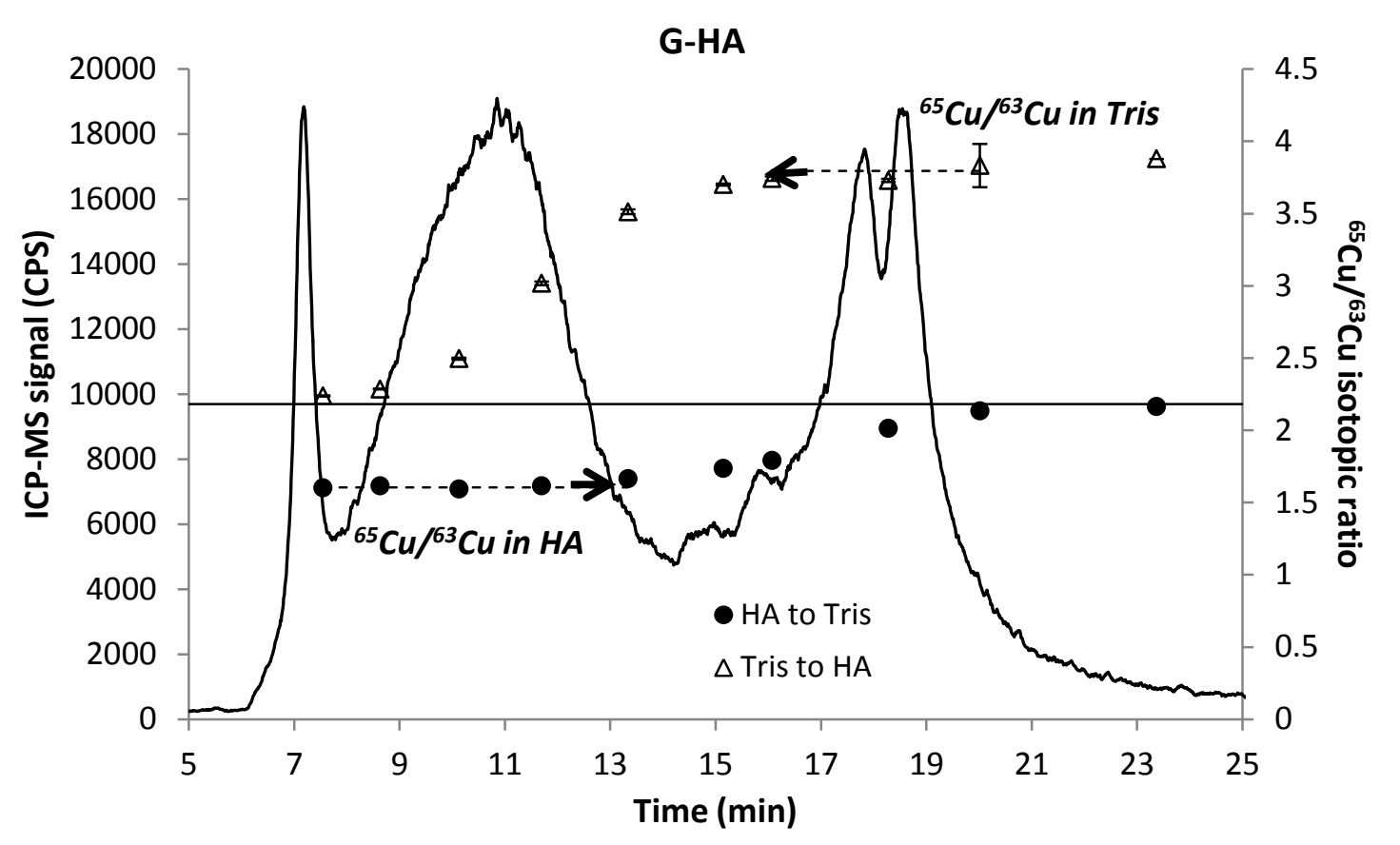

560

561 Figure 3: $\mathrm{A}{ }^{65} \mathrm{Cu}$ chromatogram of G-HA solution ( $\mathrm{pH} 7.0$ ) 72 hours after spiking with ${ }^{65} \mathrm{Cu}$ 562 (solid line). The isotopic ratio ${ }^{65} \mathrm{Cu} /{ }^{63} \mathrm{Cu}$ measured using different integration times is shown 563 where chromatograms were progressively integrated from left (solely HA) to right $(\bullet)$, or 564 from the right hand side (solely Tris-Cu complexes) to left $(\Delta)$; arrows indicate the direction 565 of integration. The broken lines represent the isotopic ratios for the HA-Cu and Tris-Cu 566 complexes. Error bars are the standard error of duplicates. 


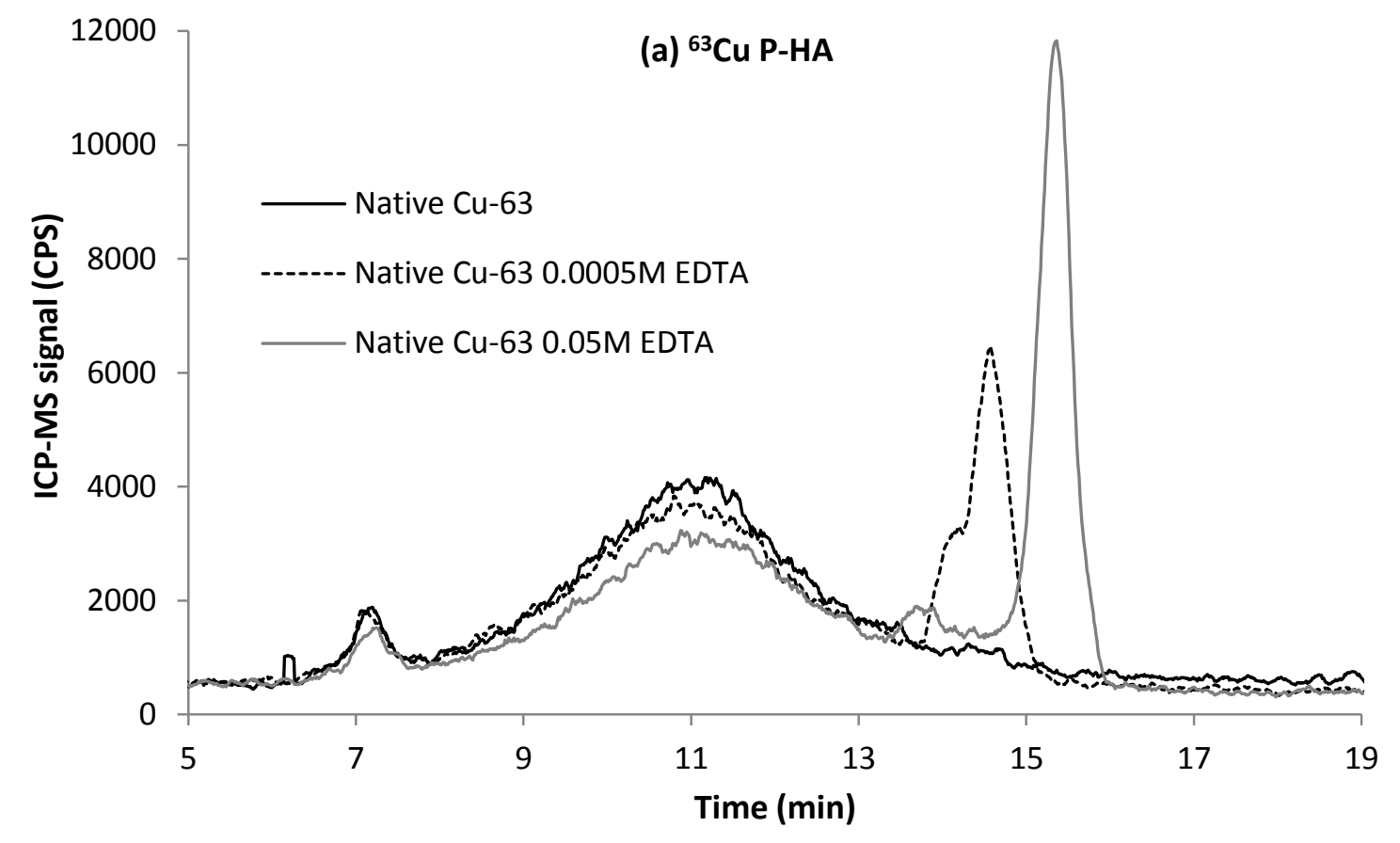

568

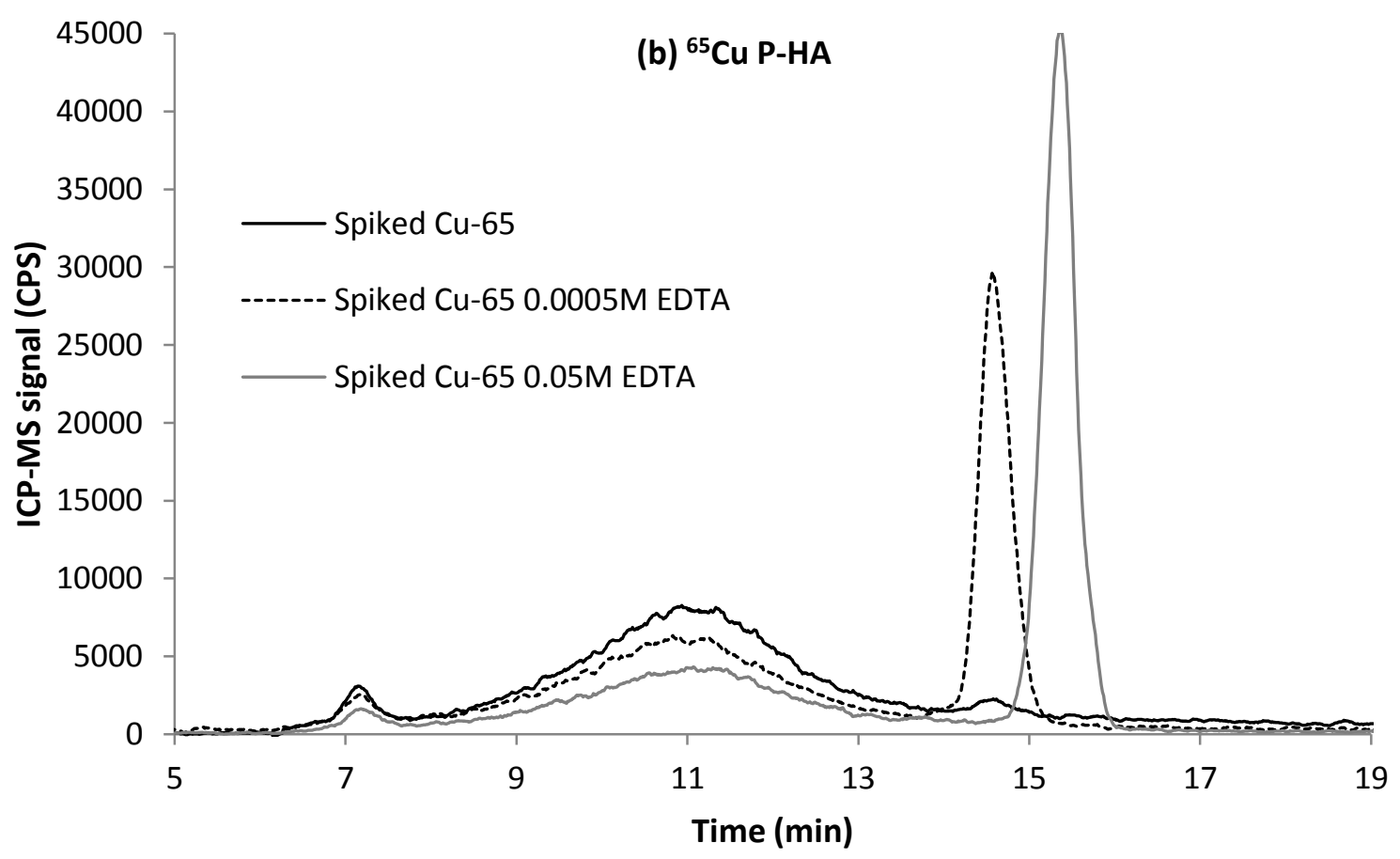

570

571 Figure 4: SEC-ICP-MS chromatograms of residual ${ }^{63} \mathrm{Cu}$ (a) and spiked ${ }^{65} \mathrm{Cu}$ (b) in peat 572 humic acid (P-HA; $\left.1.1 \mathrm{~g} \mathrm{~L}^{-1}\right)$ solutions $(\mathrm{pH} 7.0)$ at three EDTA concentrations $\left(0.0,5 \times 10^{-4}\right.$, $\left.5735 \times 10^{-2} \mathrm{M}\right)$. The HA was incubated with an enriched ${ }^{65} \mathrm{Cu}$ spike for 40 days before EDTA was 574 added. Chromatograms were run two hours after EDTA addition. 

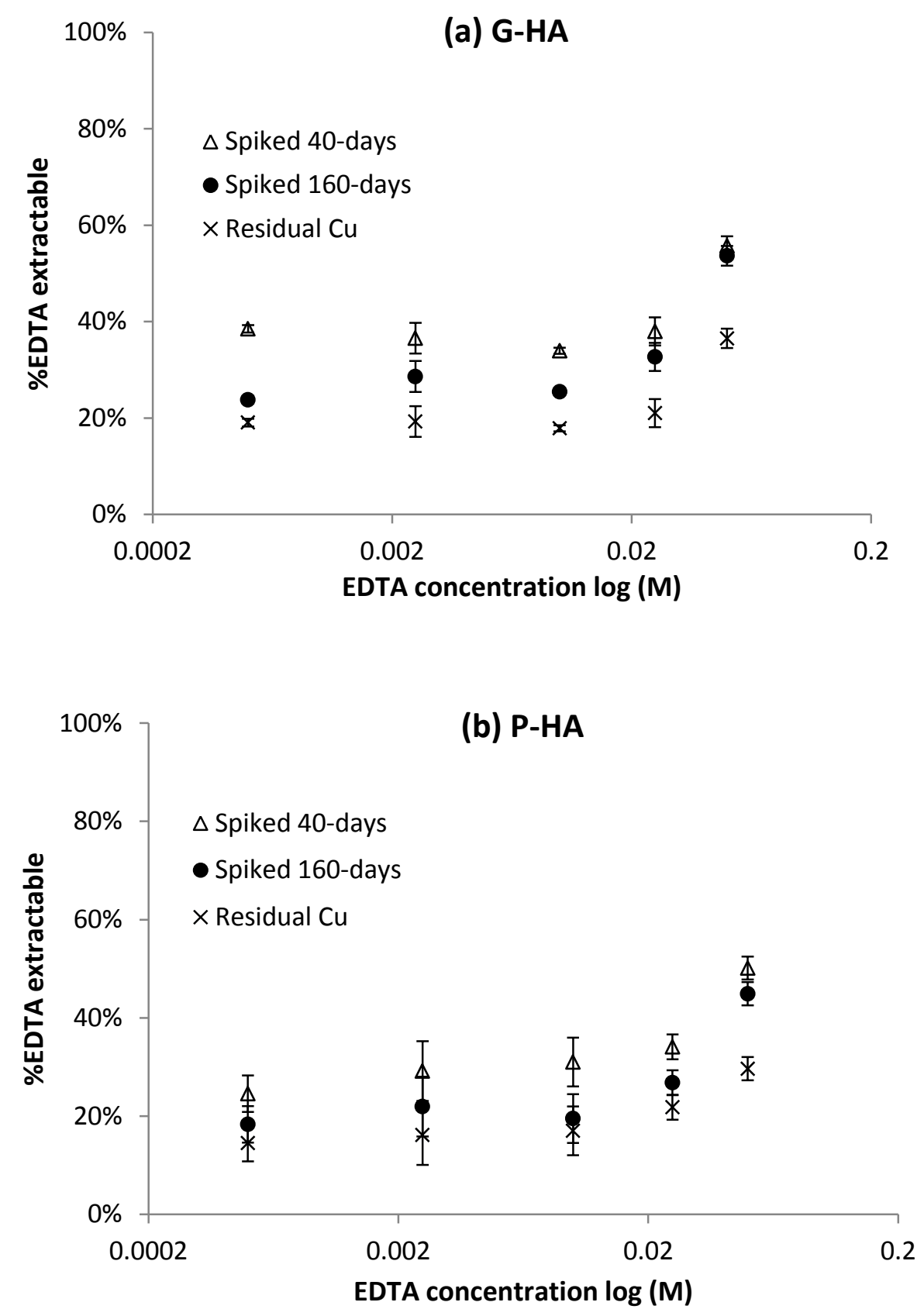

578

579

580 Figure 5: Proportion of Cu extracted by EDTA from (a) G-HA and (b) P-HA humic acids as a function of

581 EDTA concentration ( $\mathrm{M}$; $\log _{10}$ scale). Data is shown for 'residual' metal ( $\mathrm{x}$ ) present in the purified HA

582 and spiked treatment $\left({ }^{65} \mathrm{Cu}\right)$ incubated with HA for $40 \mathrm{~d}(\triangle)$ and $160 \mathrm{~d}(\bullet) \quad($ Error bars are the

583 estimated standard error between duplicates for the native ${ }^{63} \mathrm{Cu}$ isotope measured in spiked 40 -days

584 and 160-days samples. 

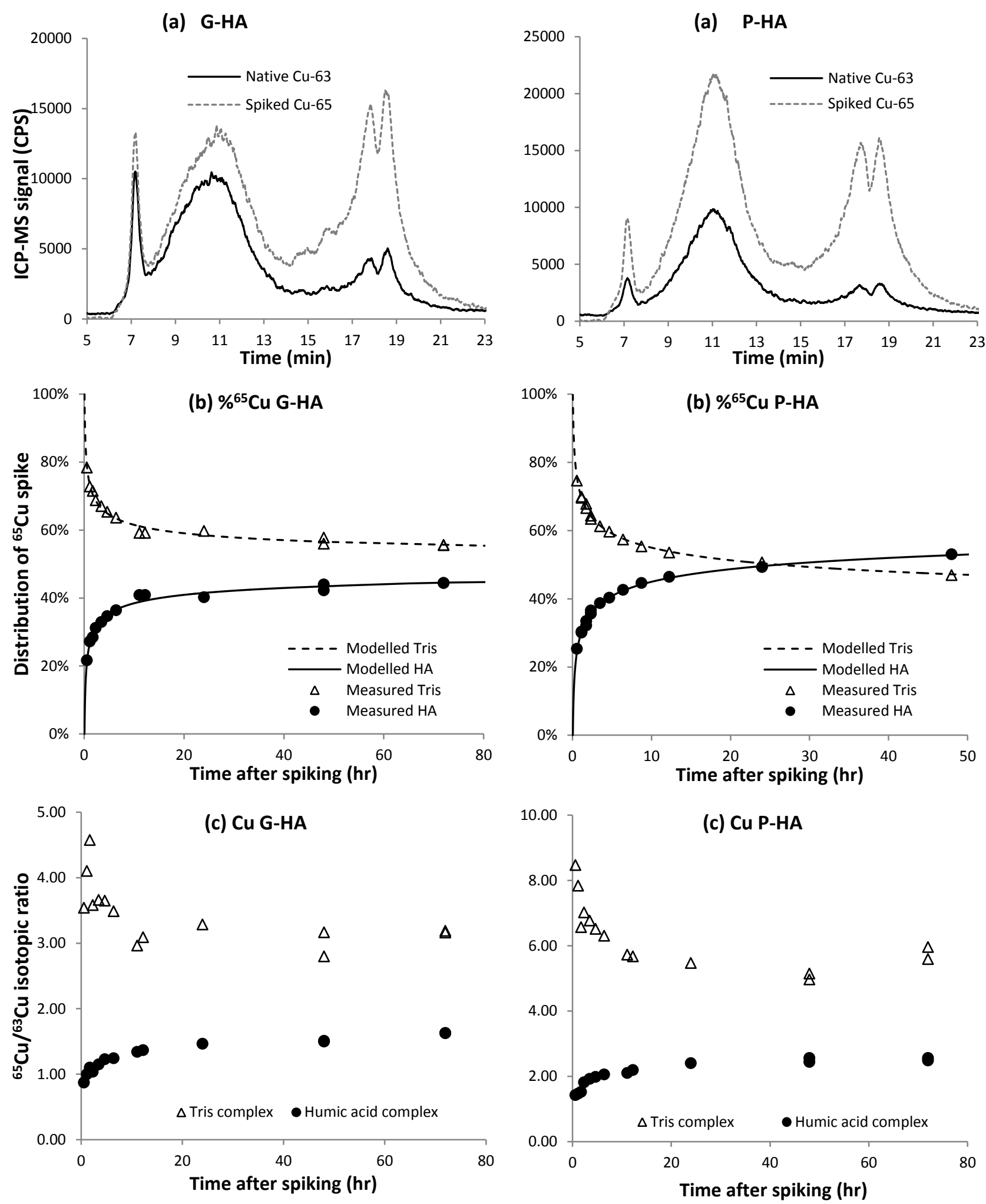

586 Figure 6: (a) SEC-ICP-MS chromatograms of spiked ${ }^{65} \mathrm{Cu}$ and incubated ${ }^{63} \mathrm{Cu}$ on grassland 587 soil humic acid (G-HA; 72 hours after spiking) and for peat humic acid (P-HA; 48 hours after 588 spiking). The humic acids were previously incubated with mixed metal standards for 40 days. 589 (b) Proportions of ${ }^{65} \mathrm{Cu}$-humic acid $(\bullet)$ and Tris $(\Delta)$ complexes in whole ${ }^{65} \mathrm{Cu}$ chromatogram 590 as a function of time after spiking; model lines are from Equation 1. (c) Isotopic ratio of $591{ }^{65} \mathrm{Cu} /{ }^{63} \mathrm{Cu}$ on humic acid $(\bullet)$ and Tris $(\Delta)$ complexes as a function of time after spiking. 
593
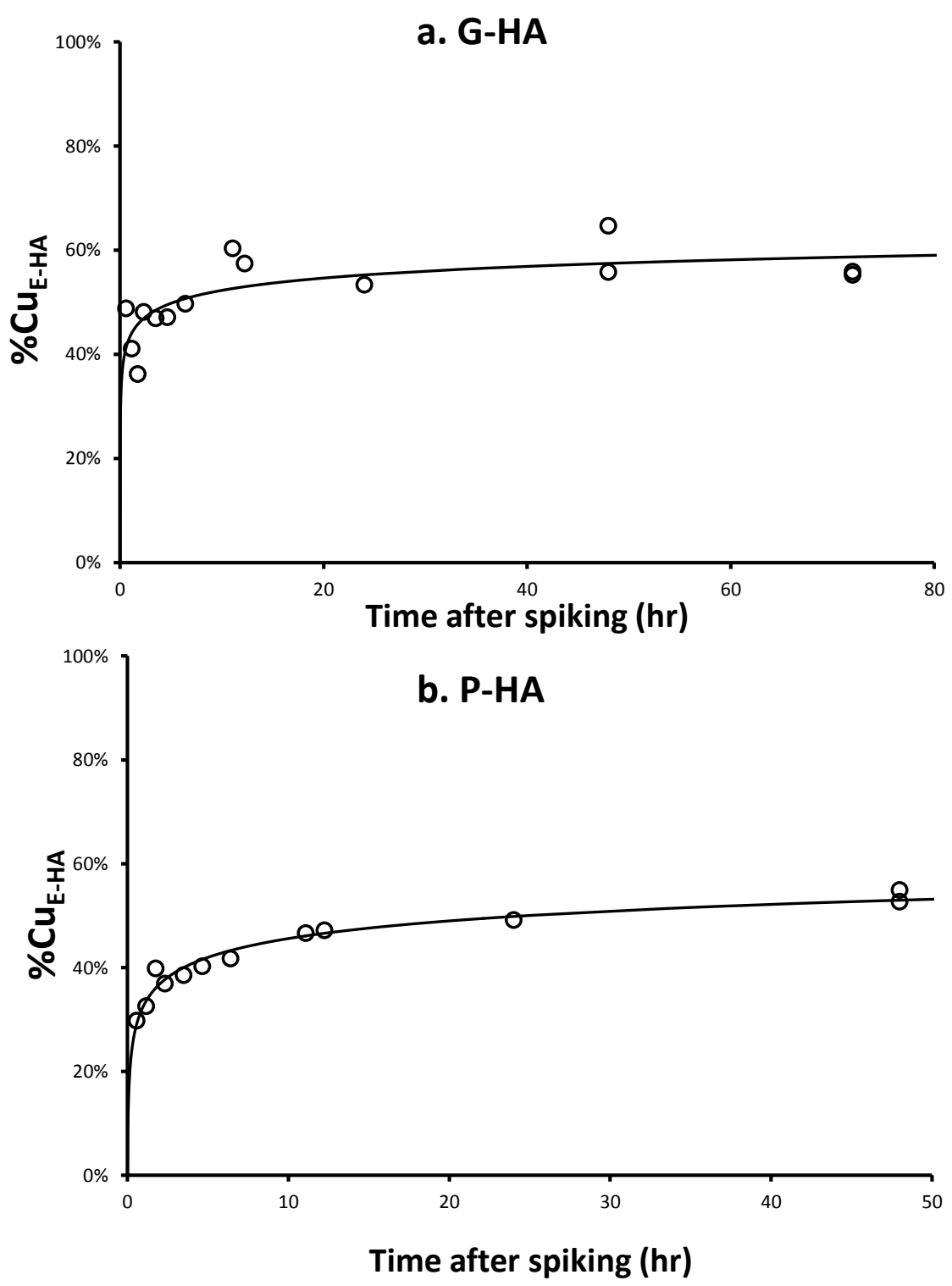

596 Figure 7: Values of $\% \mathrm{Cu}_{\mathrm{E}-\mathrm{HA}}$ on (a) grassland soil (G-HA) and (b) peat (P-HA) HAs as a

597 function of spike isotope equilibration time. The solid lines are modelled values of $\% \mathrm{Cu}_{\mathrm{E}-\mathrm{HA}}$,

598 predicted from a parameterized version of Eq. 3, as a function of time. For G-HA, $\mathrm{K}=0.762$, $\mathrm{n}=0.073(\mathrm{RSD}=4.8 \%) ;$ for $\mathrm{P}-\mathrm{HA}, \mathrm{K}=0.987, \mathrm{n}=0.093(\mathrm{RSD}=1.52 \%)$.

600

601

602 